\title{
Role of Macrophages in the Pathogenesis of Encephalomyocarditis Virus-Induced Diabetes in Mice
}

\author{
HONG-SUN BAEK AND JI-WON YOON* \\ Division of Virology, Department of Microbiology and Infectious Diseases, Faculty of Medicine, \\ and Laboratory of Viral and Immunopathogenesis of Diabetes, Julia McFarlane \\ Diabetes Research Centre, The University of Calgary, 3330 Hospital \\ Drive N.W., Calgary, Alberta T2N 4N1, Canada
}

Received 14 June 1990/Accepted 24 August 1990

\begin{abstract}
Pancreatic islets from SJL/J mice infected with the D variant of encephalomyocarditis virus (EMC-D virus) showed lymphocytic infiltration with moderate to severe destruction of beta cells. Immunohistochemical staining of the islet sections with several monoclonal antibodies, anti-Mac-1, anti-Mac-2, and F4/80 for macrophages, anti- $L_{3} T_{4}$ for helper/inducer $T$ cells, and anti-Lyt2 for cytotoxic/suppressor $T$ cells revealed that the major population of infiltrating cells at the early stage of viral infection was Mac-2-positive macrophages. In contrast, macrophages detected by anti-Mac-1 and F4/80 monoclonal antibodies were not found at the early stage of viral infection but were found at intermediate and late stages of viral infection. Helper/inducer $T$ cells and cytotoxic/suppressor $T$ cells also infiltrated the islets at intermediate and late stages of viral infection. Short-term treatment of mice with silica prior to viral infection resulted in an enhancement of beta-cell destruction, leading to the development of diabetes. In contrast, long-term treatment of mice with silica resulted in complete prevention of diabetes caused by a low dose of viral infection and a significant decrease in the incidence of diabetes caused by an intermediate or high dose of viral infection. Furthermore, depletion of macrophages by a specific monoclonal antibody (anti-Mac-2) resulted in a much greater decrease in the incidence of diabetes caused by an intermediate dose of viral infection. However, suppression of helper/inducer $T$ cells and cytotoxic/suppressor $T$ cells, by anti- $L_{3} T_{4}$ and anti-Lyt 2 antibodies, respectively, did not alter the incidence of diabetes. On the basis of these data, it is concluded that macrophages, particularly Mac-2-positive macrophages, play a crucial role in the process of pancreatic beta-cell destruction at the early stage of encephalomyocarditis D virus infection in SJL/J mice.
\end{abstract}

Type 1 diabetes results from the destruction of pancreatic beta cells. During the last several decades, genetic factors, autoimmunity, and viral infections have been extensively studied as the possible cause of type 1 diabetes. The evidence for virus-induced diabetes comes largely from experiments in animals $(8,17,24)$, but several studies in humans also point to viruses as a trigger of this disease in occasional cases $(8,17,24,25)$. The best experimental evidence indicating that viruses have an etiologic role in the pathogenesis of type 1 diabetes appears to be that of mice infected with encephalomyocarditis (EMC) virus $(8,17,24)$. In genetically susceptible mice, the $M$ variant of EMC virus (EMC-M virus) induces a diabeteslike syndrome, characterized by hypoinsulinemia, hyperglycemia, glycosuria, polydipsia, and polyphagia. However, the development of diabetes after infection with EMC-M virus is not consistent $(21,30)$. Statistically significant differences were consistently found upon repetition of the same experiment and between cages within experimental groups (21). Plaque purification of EMC-M virus resulted in the isolation of two stable variants, one highly diabetogenic (EMC-D virus) and the other nondiabetogenic (EMC-B virus) (28). Infection of SJL/J male mice with EMC-D virus results in the destruction of beta cells, leading consistently to the development of diabetes in more than $90 \%$ of the animals. However, immune mechanisms for the destruction of beta cells by EMC-D virus remain obscure.

Several earlier studies suggest that $T$ cells may be in-

\footnotetext{
* Corresponding author.
}

volved in the destruction of beta cells in EMC-M virusinduced diabetic mice $(5,6)$. However, our previous studies show that the depletion of lymphocytes failed to alter the incidence of diabetes (27). Furthermore, athymic nude mice infected with EMC-D virus showed a response nearly identical to the diabetogenic response of heterozygous littermates. The passive transfer of concanavalin A-activated lymphocytes from mice made diabetic with EMC-D virus into normal mice failed to induce diabetes. In addition, the treatment of EMC virus-infected mice with cyclosporin A enhanced both the incidence and severity of diabetes rather than preventing the disease (23). On the basis of these observations, it appears clear that $T$ cells may not play a primary role in the destruction of beta cells. The present investigation was initiated to determine whether macrophages play a role in the destruction of beta cells in EMC-D virus-induced diabetic animals. We now report that in EMC-D virus-infected SJL/J mice, depletion of macrophages by long-term treatment with silica or anti-Mac-2 monoclonal antibody (MAb) results in the prevention of diabetes.

\section{MATERIALS AND METHODS}

Virus. The source and preparation of EMC-D virus are described elsewhere (28). Virus pools were prepared from L929 cells, and the virus titer was determined by plaque assay on L929 cells (4).

Mice. Male SJL/J mice were obtained from the Jackson Laboratory, Bar Harbor, Maine, and housed in the animal facility in the Health Sciences Centre, University of Calgary, Calgary, Alberta, Canada. Except when noted, 5-week-old 
mice were used. A total of 225 mice divided into five groups (45 mice per group) were used for this study. Each group of mice was divided into three subgroups of 15 mice, and these three subgroups were inoculated intraperitoneally with $5.0 \times$ $10^{1}, 1.0 \times 10^{3}$, and $1.0 \times 10^{5}$ PFU of virus per mouse.

EMC-D virus was injected intraperitoneally into the first group of mice $\left(5.0 \times 10^{1} \mathrm{PFU}\right.$ for 15 mice, $1.0 \times 10^{3} \mathrm{PFU}$ for 15 mice, and $1.0 \times 10^{5}$ PFU for 15 mice) without any pretreatment of the animals, and this group was used as a positive control. The second, third, fourth, and fifth groups of mice were treated with silica $(100 \mathrm{mg} / \mathrm{kg}$ of body weight, intraperitoneally) for $1,2,3$, and 4 weeks, respectively, and subsequently received EMC-D virus as described for the first group.

In addition, eight $\mathrm{SJL} / \mathrm{J}$ male mice were given MAb (anti-Mac-2) against macrophages. Twice (on days -2 and $-1)$ prior to EMC-D virus infection $\left(1 \times 10^{3}\right.$ PFU per mouse), 2 mg of anti-Mac-2 MAb was injected intraperitoneally into the $\mathrm{SJL} / \mathrm{J}$ male mice. These animals also received $2 \mathrm{mg}$ of the antibody, intraperitoneally, twice (on days +1 and +2 ) after viral infection.

Fourteen SJL/J male mice were treated with $1 \mathrm{mg}$ of anti- $\mathrm{L}_{3} \mathrm{~T}_{4} \mathrm{MAb}$ three times (on days $-3,-2$, and -1 ) prior to viral infection $\left(1.0 \times 10^{3} \mathrm{PFU}\right.$ per mouse) and once (on day +1 ) after viral infection. Fourteen mice were treated similarly with anti-Lyt2 MAb. In addition, 14 mice were treated with the combined MAbs $\left(0.5 \mathrm{mg}\right.$ of anti- $\mathrm{L}_{3} \mathrm{~T}_{4}$ antibody and $0.5 \mathrm{mg}$ of anti-Lyt 2 antibody) as described above. As a positive control, $10 \mathrm{SJL} / \mathrm{J}$ male mice were infected with EMC-D virus $\left(1.0 \times 10^{3} \mathrm{PFU}\right.$ per mouse) alone. As a negative control, another $10 \mathrm{SJL} / \mathrm{J}$ male mice remained uninfected.

MAbs. Hybridoma cell lines including M3/38.1.2.8 HL2 for the production of anti-Mac-2 MAb, M1/70.15.11.5 for the production of anti-Mac-1 MAb, Gk 1.5 for the production of anti- $\mathrm{L}_{3} \mathrm{~T}_{4} \mathrm{MAb}$, and 53-6.72 for the production of anti-Lyt 2 MAb were obtained from the American Type Culture Collection, Rockville, Md., and grown in tissue culture. F4/80 MAb was kindly provided by $L$. Guilbert, University of Alberta, Edmonton, Alberta, Canada. The supernatant was harvested and stored at $-20^{\circ} \mathrm{C}$ until use. These MAbs were tested for specificity before use. The anti-Mac-1, anti-Mac-2, and $\mathrm{F} 4 / 80$, the anti- $\mathrm{L}_{3} \mathrm{~T}_{4}$, and the anti-Lyt2 MAbs recognized the murine macrophages, helper/inducer $T$ cells, and cytotoxic/suppressor $\mathrm{T}$ cells, respectively. The anti-Mac-2 MAb appears to be specific for the mononuclear phagocyte subpopulation (12).

Silica. Silica was obtained from Steinkohle-BergbauVerein, Essen, Federal Republic of Germany. Each mouse received silica at a dose of $100 \mathrm{mg} / \mathrm{kg}$ of body weight (14), intraperitoneally, twice per week from 5 to 8 weeks of age.

Glucose and ketone levels in urine. Beginning 3 days after infection with virus, glucose and ketone levels in urine were measured each day with Diastix and Ketostix reagent strips (Ames Division, Miles Laboratories Ltd., Etobicoke, Ontario, Canada), respectively.

Assay of glucose levels in blood. Glucose levels were measured in blood from the retro-orbital venous plexus by use of a glucose oxidase assay with $\boldsymbol{O}$-dianisidine dihydrochloride as the indicator dye (28). Nonfasting glucose levels in blood were measured twice, at 7 and 10 days after infection, and the mean value of the two measurements was determined. The mean nonfasting glucose level of 45 uninfected SJL/J male mice was $158 \pm 19 \mathrm{mg} / \mathrm{dl}$. In these experiments, any mouse with a nonfasting glucose level greater than $215 \mathrm{mg} / \mathrm{dl}$ (3 standard deviations [SD] above the mean) was scored as diabetic. Approximately $75 \%$ of these diabetic animals were positive for glucose in the urine $(>3$ positive with Diastix strips).

Extraction of insulin and measurement of insulin by radioimmunoassay. Insulin was extracted from the pancreas of mice by methods described elsewhere (9). The concentration of insulin from pancreas or plasma was measured by radioimmunoassay techniques as described previously (10).

Immunohistochemical staining of pancreatic sections. For immunohistochemical examination of pancreatic sections, mice were sacrificed at $12,24,36,48,60,72,96,120,144$, and $168 \mathrm{~h}$ after infection. The splenic pancreas was removed, excised, and immediately frozen at $-70^{\circ} \mathrm{C}$. Sections $(4.5 \mu \mathrm{m})$ of frozen pancreas were air dried for $35 \mathrm{~min}$, fixed with acetone for $10 \mathrm{~min}$, air dried again for $20 \mathrm{~min}$, and stored at $-20^{\circ} \mathrm{C}$ until use. Sequential sections were incubated with 30 $\mu l$ of anti-Mac-1, anti-Mac-2, F4/80, anti- $\mathrm{L}_{3} \mathrm{~T}_{4}$, and anti-Lyt2 (10 to $20 \mu \mathrm{g} / \mathrm{ml}$ in phosphate-buffered saline) for $90 \mathrm{~min}$ at room temperature. After a 15-min wash in phosphate-buffered saline, the tissues were incubated with fluoresceinlabeled anti-rat immunoglobulin (Kirkegaard and Perry Laboratories, Gaithersburg, Md.). The sections were washed again in phosphate-buffered saline and examined with an Olympus fluorescence microscope.

Histological examination. At 9 days after infection, several mice per group were sacrificed and $50 \%$ of each pancreas was fixed in $6 \%$ Formalin. Paraffin-embedded sections were stained with hematoxylin and eosin and examined.

Statistical analysis. Statistical significance was assessed by Fisher's exact test (22).

\section{RESULTS}

Distribution of immunocytes in pancreatic islets at different times after EMC-D virus-infection. To determine what kinds of immunocytes infiltrate the pancreatic islets first, serial sections of pancreas from 10 mice, at different times after infection, were stained with several MAbs: anti-Mac-1, anti-Mac-2, and F4/80 for macrophages; anti- $\mathrm{L}_{3} \mathrm{~T}_{4}$ for helper/ inducer $\mathrm{T}$ cells; and anti-Lyt 2 for cytotoxic/suppressor $\mathrm{T}$ cells. At 12 to $36 \mathrm{~h}$ after infection, most infiltrated immunocytes were stained by anti-Mac- 2 antibody but not by anti-Mac-1 and F4/80 (pictures not shown), anti- $\mathrm{L}_{3} \mathrm{~T}_{4}$, or anti-Lyt2 (Fig. 1A to C). At 48 to $72 \mathrm{~h}$ after infection, the infiltrated immunocytes in the islets were stained by all the tested MAbs (Fig. 1D to I) (anti-Mac-1 and F4/80 positive pictures not shown). These results indicate that the major population of infiltrating cells in early insulitis are Mac-2positive macrophages.

Effect of virus dose on the induction of diabetes. To see whether the severity of diabetes is dependent upon the virus dose, we inoculated mice with $5.0 \times 10^{1}, 1.0 \times 10^{3}$, and 1.0 $\times 10^{5}$ PFU per mouse; $47 \%$ of mice infected with the low dose of virus, $93 \%$ of mice infected with the intermediate dose of virus, and $100 \%$ of mice infected with the high dose of virus became diabetic within 1 week. The mean glucose level in blood $(256 \pm 41 \mathrm{mg} / \mathrm{dl})$ of diabetic animals given the low dose of virus was lower than the levels ( $333 \pm 59$ and 359 $\pm 89 \mathrm{mg} / \mathrm{dl}$ ) in mice infected with the intermediate and high doses (Table 1). There was no significant difference in the glucose levels in blood between intermediate- and high-dose virus-infected groups, although the mean level $(359 \pm 89$ $\mathrm{mg} / \mathrm{dl}$ ) in diabetic animals infected with the high dose of virus was slightly higher than that $(333 \pm 59 \mathrm{mg} / \mathrm{dl})$ in diabetic animals infected with the intermediate dose. The immunoreactive insulin levels in the pancreas were inversely parallel 

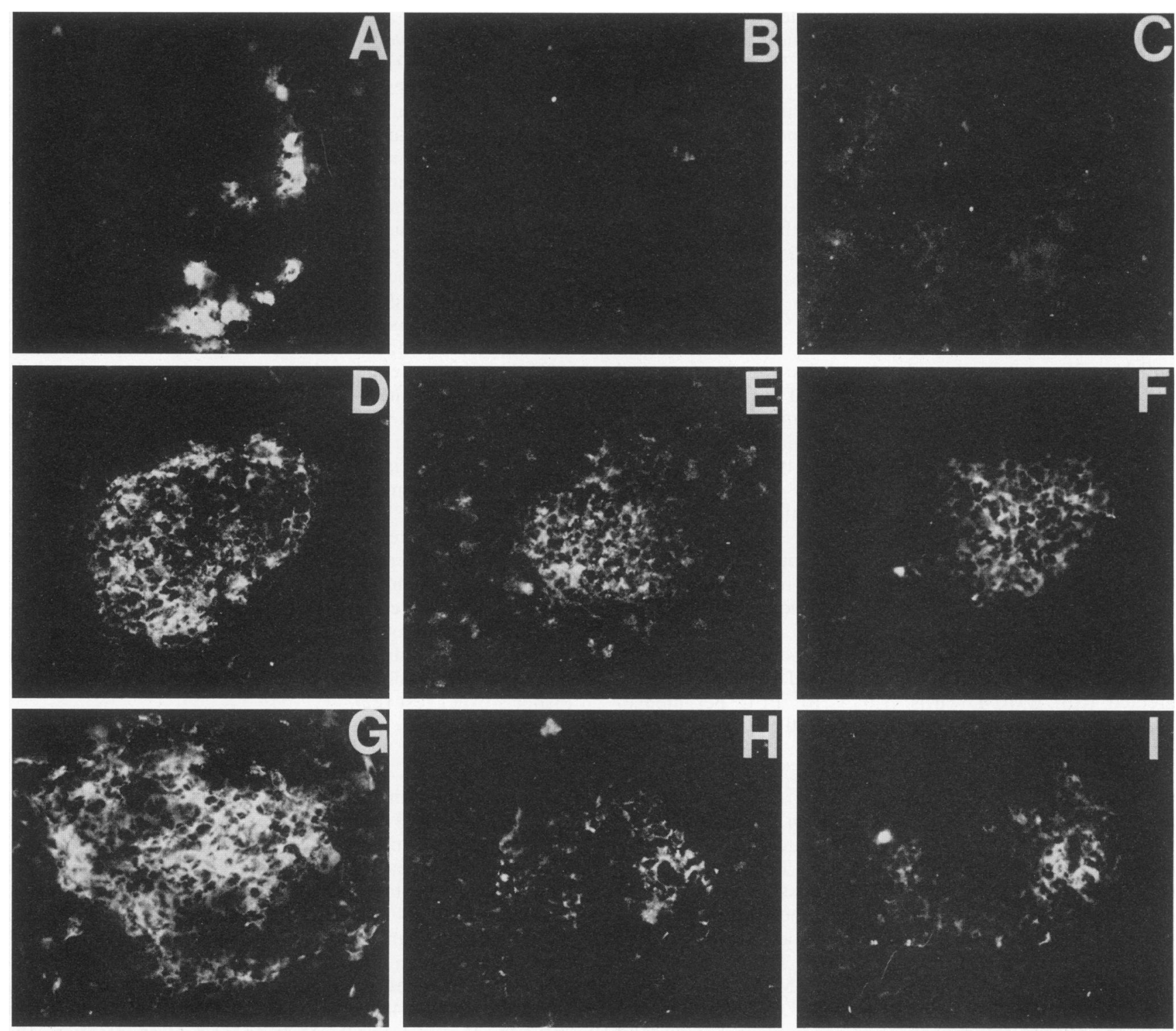

FIG. 1. Serial cryosections of pancreas at $12 \mathrm{~h}$ (A to C), $60 \mathrm{~h}$ (D to F), and $144 \mathrm{~h}$ (G to I) after infection with EMC-D virus were stained by indirect immunofluorescence with the following MAbs: anti-Mac-2 (panels A, D, and G), anti- $\mathrm{L}_{3} \mathrm{~T}_{4}$ (panels B, E, and H), anti-Lyt2 (panels $\mathrm{C}, \mathrm{F}$, and I). At $12 \mathrm{~h}$ after infection, most infiltrated immunocytes were positive for anti-Mac-2 (A) but negative for both anti- $\mathrm{L}_{3} \mathrm{~T}_{4}(\mathrm{~B})$ and anti-Lyt2 (C). At $60 \mathrm{~h}$ after infection, the infiltrated immunocytes in the islet were positive for all tested MAbs: anti-Mac-2 (D), anti- $\mathrm{L}_{3} \mathrm{~T}_{4}(\mathrm{E})$, and anti-Lyt2 (F). At $144 \mathrm{~h}$ after infection, many infiltrated immunocytes in the center of the islet remained positive for anti-Mac-2 (G) and some immunocytes in the periphery of the islet were positive for anti- $\mathrm{L}_{3} \mathrm{~T}_{4}(\mathrm{H})$ and anti-Lyt2 (I). Magnification $\times 150$.

to the glucose levels in blood (Table 1), as were the insulin levels in plasma (Table 1).

Effect of silica on the prevention of diabetes in EMC-D virus-infected mice. To see whether macrophages are involved in the destruction of beta cells, leading to the development of diabetes, we treated mice with silica (which is known to be toxic to macrophages) for $1,2,3$, or 4 weeks and subsequently gave them different doses of virus (low, intermediate, and high doses as described above). In mice treated with silica for 1 week, the incidence and severity of diabetes in the low-dose virus-infected group were higher than those in the untreated group $(P<0.01)$ (Fig. $2 \mathrm{~A})$. In contrast, none of the low-dose virus-infected mice treated with silica for 2 weeks or more became diabetic, whereas approximately $47 \%$ of the untreated group became diabetic
TABLE 1. Effect of virus dose on the severity of diabetes ${ }^{a}$

\begin{tabular}{ccccc}
\hline $\begin{array}{c}\text { Virus dose } \\
(\mathrm{PFU} / \mathrm{mouse})\end{array}$ & $\begin{array}{c}\text { Mean blood } \\
\text { glucose } \pm \\
\text { SD }(\mathrm{mg} / \mathrm{dl})\end{array}$ & $\begin{array}{c}\text { Mean pancreatic } \\
\text { insulin } \pm \mathrm{SD}^{b} \\
(\mu \mathrm{g} / \mathrm{g} \text { of pancreas })\end{array}$ & $\begin{array}{c}\text { Mean plasma } \\
\text { insulin } \pm \mathrm{SD} \\
(\mathrm{ng} / \mathrm{ml})\end{array}$ & $\begin{array}{c}\% \text { of } \\
\text { mice with } \\
\text { diabetes }^{c}\end{array}$ \\
\hline 0 & $158 \pm 19$ & $156 \pm 23$ & $4.2 \pm 0.5$ & 0 \\
$5.0 \times 10^{1}$ & $256 \pm 41$ & $48 \pm 11$ & $2.6 \pm 0.3$ & 47 \\
$1.0 \times 10^{3}$ & $333 \pm 59$ & $22 \pm 6$ & $1.7 \pm 0.2$ & 93 \\
$1.0 \times 10^{5}$ & $359 \pm 89$ & $19 \pm 5$ & $1.5 \pm 0.2$ & 100 \\
\hline
\end{tabular}

${ }^{a}$ Each group contained 7 to 15 mice.

${ }^{b}$ Pancreases from SJL/J mice were weighed, and the insulin content was determined.

$c$ The mean nonfasting glucose level in blood of 45 uninfected SJL/J male mice was $158 \pm 19 \mathrm{mg} / \mathrm{dl}$. Any mouse with a nonfasting level greater than 215 $\mathrm{mg} / \mathrm{dl}$ ( $3 \mathrm{SD}$ above the mean of the uninfected control mice) was scored as diabetic. 


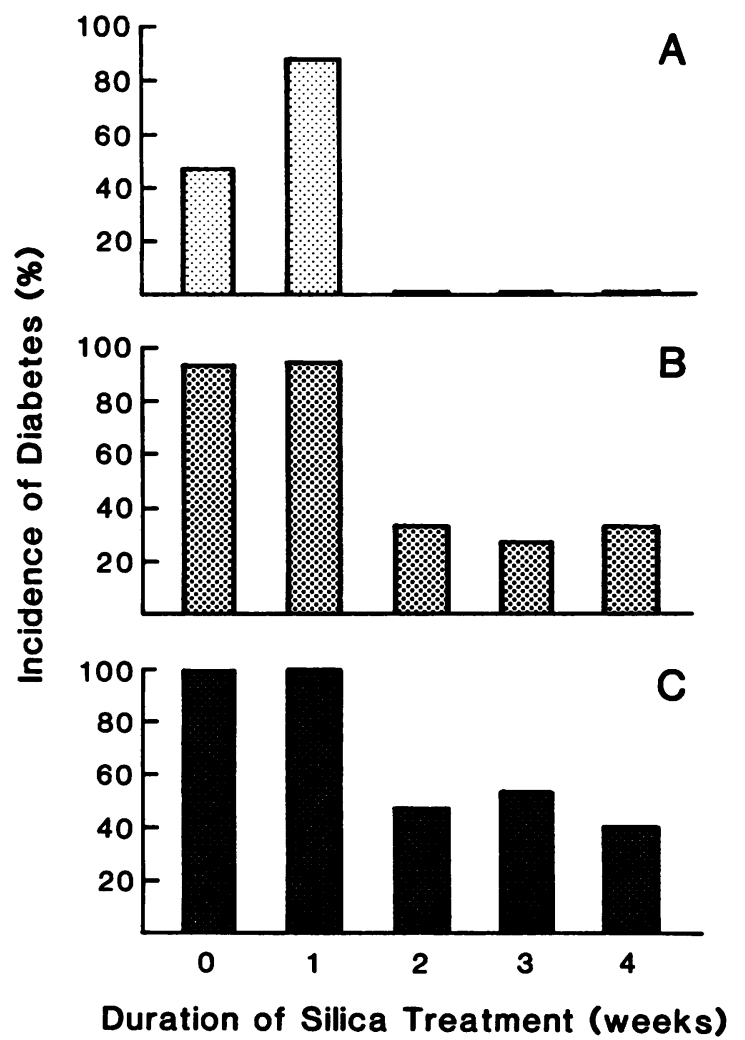

FIG. 2. Effect of silica pretreatment on the development of diabetes in EMC-D virus-infected mice. Male SJL/J mice were treated with silica for 1 to 4 weeks and subsequently given different doses of virus: $5.0 \times 10^{1} \mathrm{PFU}$ per mouse (A), $1.0 \times 10^{3} \mathrm{PFU}$ per mouse (B), and $1.0 \times 10^{5} \mathrm{PFU}$ per mouse (C). Nonfasting glucose levels in blood were measured at 7 and 10 days after virus infection. The mean value of the two measurements was calculated. Any mouse with a nonfasting glucose level greater than $215 \mathrm{mg} / \mathrm{dl}$ (3 SD above the mean of the uninfected control mice) was scored as diabetic. Each group contained 15 mice.

$(P<0.001)$ (Fig. 2A). In the intermediate- and high-dose virus-infected groups, 30 to $50 \%$ of the mice treated with silica for 2 weeks or more became diabetic, whereas more than $90 \%$ of the untreated groups developed diabetes $(P<$ 0.01) (Fig. 2B and C). There was no statistically significant difference in the incidence of diabetes among 2,3 , and 4-week-silica-treated groups regardless of the virus dose (Fig. 2A to $\mathrm{C}$ ). In addition, there was no significant difference in the incidence of diabetes between intermediate- and high-dose virus-infected groups which received silica for 2 weeks or more (Fig. 2B and C).

Examination of islets from the silica-treated nondiabetic mice showed minimal or no inflammation (Fig. 3C). The architecture of islets from these animals was nearly intact, very similar to that of islets from uninfected control mice (Fig. 3A). The difference in islet architecture of the silicatreated nondiabetic mice, and that of the uninfected controls was the disarray of the islet cells and occasional minimal peri-islet mononuclear-cell infiltration in the former (Fig. 3C). In contrast, most islets from positive control mice (virus infected, no silica treatment) showed severe destruction of islet cells with extensive inflammatory infiltrate (e.g., mononuclear cells) (Fig. 3B).

Effect of anti- $L_{3} T_{4}$ and anti-Lyt2 antibodies on the development of diabetes in EMC-D virus-infected mice. To see whether T-cell suppression had any effect on virus-induced diabetes, we determined glucose levels in the blood of infected and uninfected mice treated with anti- $\mathrm{L}_{3} \mathrm{~T}_{4}$ antibody or anti-Lyt 2 antibody or both. There was no significant difference in the frequency of virus-induced diabetes or the extent of hyperglycemia between the treated and untreated animals (Table 2).

Effect of anti-Mac-2 MAb on the development of diabetes in EMC-D virus-infected mice. To determine unequivocally whether macrophages play a role in the destruction of beta cells of EMC virus-infected mice, a specific MAb (antiMac-2) against a subpopulation of macrophages was injected into $\mathrm{SJL} / \mathrm{J}$ male mice before and after viral infection. More than $90 \%$ (10 of 11$)$ of the untreated animals became diabetic, whereas only about $25 \%$ ( 2 of 8 ) of the anti-Mac-2 antibody-treated animals developed diabetes (Fig. 4). These results indicate that Mac-2-positive macrophages play a significant role in the process of beta-cell destruction in the early stage of EMC-D virus infection in SJL/J mice.

\section{DISCUSSION}

The best experimental evidence indicating that viruses have an etiological role in the pathogenesis of diabetes appears to be that of mice infected with EMC virus $(8,17$, $24)$. Genetic factors of the host $(18,26,29)$ and molecular identification of the viral gene(s) responsible for the induction of diabetes $(3,4,7,31)$ have been extensively studied. The susceptibility to EMC virus-induced diabetes is determined by an autosomal recessive gene which may be controlled by a single locus and inherited in a Mendelian mode (18). Two amino acids, Phe-16 on the leader peptide and Ala-776 (152nd amino acid on the VP1) on the polyprotein, are most likely to be responsible for the diabetogenicity of EMC virus (3). However, immune mechanisms involved in the pathogenesis of diabetes in EMC virus-infected animals remain obscure.

Earlier studies suggested that $T$ cells may be involved in the destruction of beta cells in animals with EMC-M virusinduced diabetes $(5,6)$. Buschard et al. $(6)$, in experiments with two strains of nude mice, reported that these mice did not develop virus-induced diabetes, whereas their heterozygous littermates did. The mortality rate was high in some of the experiments, and the investigators infected mice with EMC-M virus, which, in the strains of mice used, did not produce severe diabetes. Our recent studies with EMC-D virus did not support T-cell-mediated destruction of beta cells in EMC virus-infected animals. We tested both athymic nude mice and thymectomized mice and found them no less susceptible than normal animals to EMC virus-induced diabetes (27). Similarly, Vialettes et al. failed to find evidence for a thymus-dependent, cell-mediated immune response in EMC-M virus-induced diabetes (23). More recently, Haynes et al. reported that $\mathrm{BALB} / \mathrm{cByJ}$ mice depleted of $\mathrm{L}_{3} \mathrm{~T}_{4}^{+}$cells exhibited a reduced incidence and severity of EMC-M virus-induced diabetes in comparison with both untreated and anti-Lyt2-treated animals (11). In contrast, our studies with EMC-D virus and SJL/J mice revealed no significant difference in the incidence of virusinduced diabetes or the extent of hyperglycemia between anti- $\mathrm{L}_{3} \mathrm{~T}_{4}$ antibody-treated and untreated animals (Table 2). The different findings among laboratories may be due, in part, to the exquisite sensitivity of EMC virus to interferon. Subtle differences in the interferon response of different strains of mice, or differences in the induction of interferon by immunosuppression, could influence the development of 

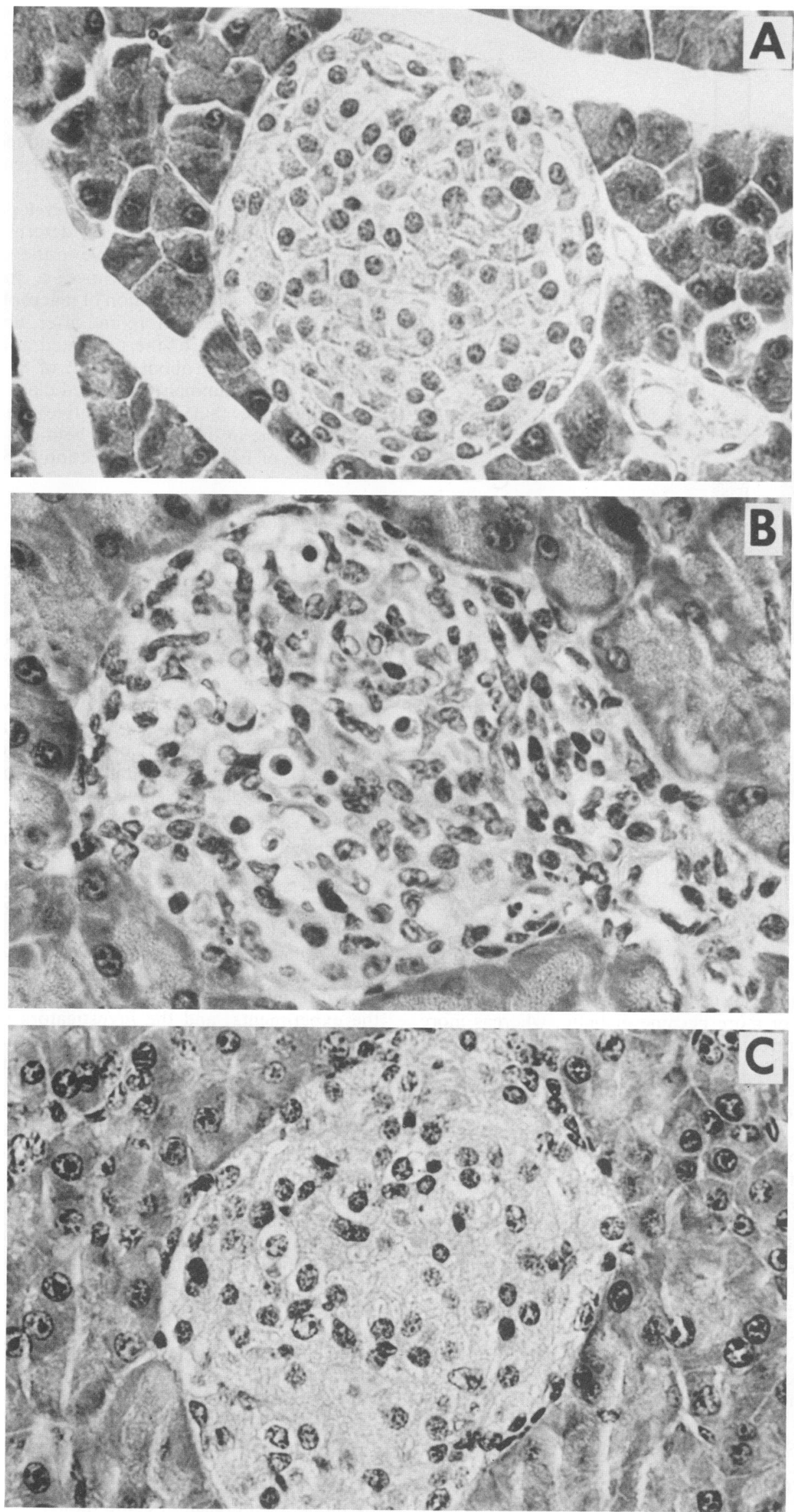
TABLE 2. Effect of anti- $\mathrm{L}_{3} \mathrm{~T}_{4}$ and anti-Lyt2 MAbs on the incidence and severity of diabetes ${ }^{a}$

\begin{tabular}{clcc}
\hline $\begin{array}{c}\text { EMC-D } \\
\text { virus }\end{array}$ & \multicolumn{1}{c}{$\begin{array}{c}\text { Antibodies to } \\
\text { lymphocytes }\end{array}$} & $\begin{array}{c}\text { Mean blood } \\
\text { glucose } \pm \mathrm{SD} \\
(\mathrm{mg} / \mathrm{dl})^{b}\end{array}$ & $\begin{array}{c}\% \text { of mice } \\
\text { with diabetes }\end{array}$ \\
\hline- & & $161 \pm 18$ & 0 \\
+ & & $320 \pm 55$ & 90 \\
+ & Anti- $\mathrm{L}_{3} \mathrm{~T}_{4}$ & $306 \pm 66$ & 71 \\
+ & Anti-Lyt & 86 \\
+ & Anti- $\mathrm{L}_{3} \mathrm{~T}_{4}+$ anti-Lyt & $333 \pm 56$ & 79 \\
\hline
\end{tabular}

${ }^{a}$ Each group contained 10 to 14 mice.

${ }^{b} \mathrm{SJL} / \mathrm{J}$ mice were treated with anti- $\mathrm{L}_{3} \mathrm{~T}_{4}$, anti-Lyt2, or both, three times over a period of 3 days (on days $-3,-2$, and -1 ) prior to viral infection and once (on day +1 ) after viral infection. Nonfasting glucose levels in blood were measured at 7 and 10 days after infection. The mean value of the two measurements was determined.

$c$ Any mouse with a nonfasting glucose level greater than $215 \mathrm{mg} / \mathrm{dl}$ (3 SD above the mean of the uninfected control mice) was scored as diabetic.

virus-induced diabetes. Moreover, the EMC-M virus pool used by several of the laboratories is a mixture of the diabetogenic EMC-D virus variant and the nondiabetogenic EMC-B virus variant (28). EMC-B virus, in contrast to EMC-D virus, is a good interferon inducer and protects beta cells from infection by EMC-D virus. The ratio of these two variants determines the severity of the resulting diabetes (28). In our experiments, we attempted to avoid this problem by using the newly plaque-purified EMC-D virus, which does not produce interferon at all (28). In addition, the possible influence of strain difference on the effect of anti$\mathrm{L}_{3} \mathrm{~T}_{4}$ antibody (11) cannot be excluded. Nevertheless, repeated experiments consistently showed that depletion of helper/inducer $\mathrm{T}$ cells by anti- $\mathrm{L}_{3} \mathrm{~T}_{4}$ antibody or of cytotoxic/ suppressor $\mathrm{T}$ cells by anti-Lyt 2 antibody, or both, did not alter the incidence or severity of EMC-D virus-induced diabetes in SJL/J mice in comparison with those in untreated mice.

Our present data, as determined by various MAbs against mouse immunocytes, showed that Mac-2-positive macrophages were predominant at an early stage of viral infection, whereas mixed immunocytes, including Mac-2-positive and F4/80-positive macrophages, helper/inducer $T$ cells, and cytotoxic/suppressor $\mathrm{T}$ cells, were present at intermediate and late stages of viral infection. It was previously reported that Mac-2 expression is induced only by strong inflammatory stimuli and appears to be specific for mononuclear phagocyte subpopulations (12). Thus, it is reasonable to consider that Mac-2-positive macrophages are actively involved in the process of destruction of beta cells infected with EMC-D virus. To see whether macrophages truly play a role in the destruction of beta cells, leading to the development of diabetes, we treated mice with silica (known to be toxic to macrophages) for a short or long duration and subsequently gave them a low, intermediate, or high dose of virus. Short-term treatment of mice with silica, prior to viral infection, significantly enhanced the incidence of diabetes in mice inoculated with a low dose of EMC virus (50 PFU per mouse). This is probably due to the activation of macrophages which are, possibly, actively involved in the process

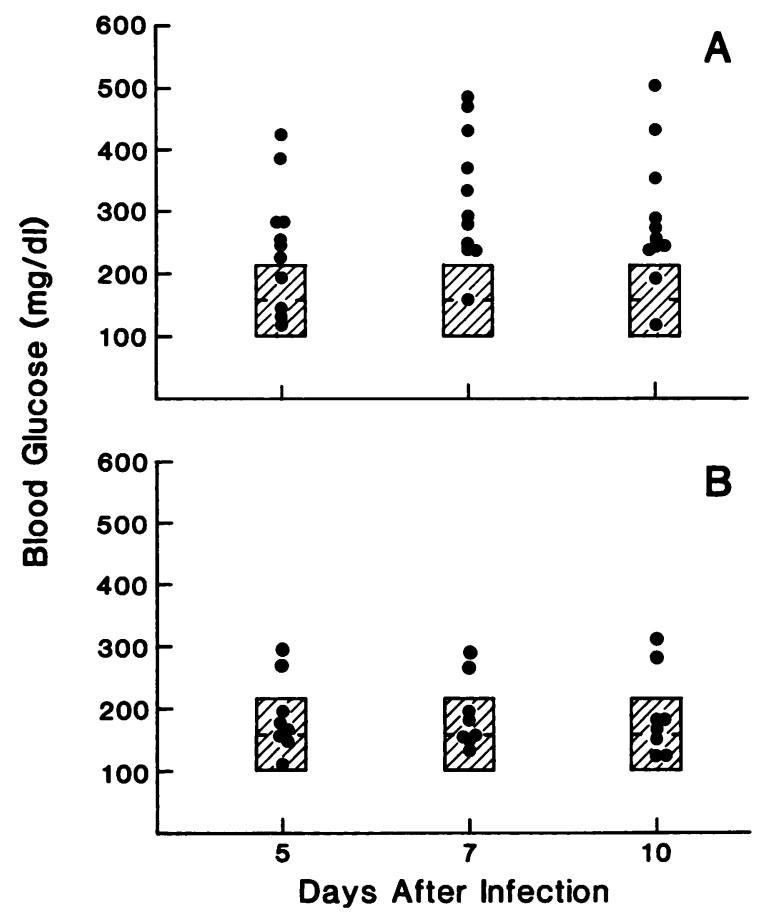

FIG. 4. Effect of anti-Mac-2 MAb on the development of diabetes in EMC-D virus-infected mice. (A) SJL/J mice infected with EMC-D virus $\left(1 \times 10^{3}\right.$ PFU per mouse, intraperitoneally $)$ alone. (B) $\mathrm{SJL} / \mathrm{J}$ mice treated with anti-Mac-2 MAb 1 and 2 days before and after EMC-D virus infection $\left(1 \times 10^{3}\right.$ PFU per mouse, intraperitoneally). Nonfasting glucose levels in blood were measured at 5,7 , and 10 days after virus infection. Shaded areas represent the mean glucose level \pm 3 standard deviations for 45 uninfected $\mathrm{SJL} / \mathrm{J}$ mice. Each point represents an individual animal.

of beta-cell destruction in EMC-D virus-infected animals. In contrast, long-term treatment with silica resulted in complete prevention of diabetes in animals given a low dose of the virus. This is probably due to the depletion or inactivation of macrophages by silica. These results suggest that macrophages clearly contribute to the destruction of pancreatic beta cells, leading to the development of diabetes. However, EMC-D virus itself appears to be sufficiently cytotoxic to destroy beta cells to a certain extent when an intermediate or high dose of virus is given, since infection of mice with an intermediate or high dose of virus, after long-term silica treatment, still leads to the development of diabetes in some animals. Although the incidence of diabetes is significantly reduced in these animals, the disease is not totally prevented.

Macrophages are the major population of infiltrating immunocytes at the early stage of insulitis in diabetes-prone BioBreeding (BB) rats (14). Depletion of macrophages by long-term silica treatment resulted in the prevention of diabetes in spontaneously diabetic BB rats and nonobese diabetic (NOD) mice $(14,19)$. The prevention of insulitis and diabetes in these animals is due to a substantial decrease in

FIG. 3. Pathologic changes in the islets of Langerhans after EMC-D virus infection with and without silica treatment. All panels are stained with hematoxylin and eosin. (A) Section of pancreas from uninfected mouse, showing a normal islet surrounded by acinar cells. (B) Section of pancreas (7 days after infection) without silica treatment, showing extensive inflammatory infiltrate, with mononuclear cells in the islets of Langerhans and beta-cell necrosis. (C) Section of pancreas (7 days after infection) after 3 weeks of silica treatment, showing the intact architecture of islet with minimal inflammation and disarray. Magnification $\times 356$. 
the number of macrophage-dependent $T$ cells (1). In these animal models, the defects in macrophages could result in the inhibition of antigen recognition by $T$ cells with the subsequent curtailment of any further immune process that would lead to the destruction of the target beta cells, since the key role of macrophages includes the presentation of processed antigen to helper/inducer $T$ cells. However, the role of macrophages in mice with EMC-D virus-induced diabetes is quite different from that in animals with spontaneously developed autoimmune diabetes. Administration of anti- $\mathrm{L}_{3} \mathrm{~T}_{4}$ MAb to NOD mice prevented the development of diabetes (13). The suppression of T cells by OX19 MAb for pan-T cells or anti-lymphocyte serum resulted in the prevention of diabetes in BB rats $(15,16)$. In contrast, suppression of helper/inducer $\mathrm{T}$ cells and cytotoxic/suppressor $\mathrm{T}$ cells, by anti- $\mathrm{L}_{3} \mathrm{~T}_{4}$ and anti-Lyt 2 antibodies, respectively, did not alter the incidence of diabetes induced by EMC-D virus. Thus, it is conceivable that the presence of Mac-2-positive macrophages at an early stage of viral infection is due to scavengers present as a consequence of beta-cell damage by viral infection. These macrophages probably contribute to beta-cell destruction through the release of soluble factors such as cytokines (e.g., interleukin-1, tumor necrosis factor, $\gamma$-interferon) and free radicals (oxygen radicals) $(2,20)$. In contrast, helper/inducer $\mathrm{T}$ cells and cytotoxic/suppressor $\mathrm{T}$ cells, present at intermediate and late stages of viral infection, are probably present in the islets as passengers. Therefore, these cells may not play a primary role in pancreatic beta-cell destruction, as indicated by the fact that treatment with anti- $\mathrm{L}_{3} \mathrm{~T}_{4}$ and anti-Lyt2 MAbs did not alter the incidence of diabetes. If these cells play any role in the destruction of beta cells, their role is minimal. Mac-1-positive and F4/80-positive cells also were not present at an early stage of viral infection. These macrophages may not be involved in the destruction of beta cells at an early stage of viral infection. However, the precise function of these cells, as yet undetermined, is under investigation.

Mac-2-positive macrophages, detected at an early stage of viral infection, appear to be specific for the mononuclear phagocyte population (12). To determine whether Mac-2positive macrophages play a significant role in the destruction of beta cells in EMC-D virus-infected mice, we administered anti-Mac-2 MAb to SJL/J male mice. More than $90 \%$ of the untreated animals became diabetic, whereas only about $25 \%$ of the anti-Mac-2-treated animals developed diabetes. These results clearly indicate that Mac-2-positive macrophages play a critical role in the process of pancreatic beta-cell destruction at the early stage of EMC-D virus infection in SJL/J mice.

\section{ACKNOWLEDGMENTS}

We thank Chin Y. Pak for valuable technical advice and assistance throughout this work. We also thank $\mathrm{L}$. Guilbert for providing $\mathrm{F} 4 / 80 \mathrm{MAb}$. The editorial assistance of $\mathrm{K}$. Clarke and the secretarial help of C. Brooks are gratefully acknowledged.

This work was supported by Medical Research Council of Canada grant MA9786 and the Canadian Diabetes Association. J.-W.Y. is a Heritage Medical Scientist Awardee and Julia McFarlane Chair Professor.

\section{LITERATURE CITED}

1. Amano, K., and J. W. Yoon. 1990. Studies on autoimmunity for initiation of $\beta$-cell destruction. V. Decrease of macrophagedependent T-lymphocytes and natural killer cytotoxicity in silica-treated rats. Diabetes 39:590-596.

2. Appels, B., V. Burkart, G. Kantwerk-Funke, J. Funda, V. Kolb-Bachofen, and H. Kolb. 1989. Spontaneous cytotoxicity of macrophages against pancreatic islet cells. J. Immunol. 142: 3803-3808.

3. Bae, Y. S., H. M. Eun, R. T. Pon, D. Giron, and J. W. Yoon. 1990. Two amino acids, Phe-16 and Ala-776, on the polyprotein are most likely responsible for diabetogenicity of EMC virus. J. Gen. Virol. 71:639-645.

4. Bae, Y. S., H. M. Eun, and J. W. Yoon. 1989. Genomic differences between the diabetogenic and non-diabetogenic variants of encephalomyocarditis virus. Virology 170:282-287.

5. Buschard, K., N. Hastrup, and J. Rygaard. 1983. Virus-induced diabetes in mice and thymus-dependent immune system. Diabetologia 24:42-46.

6. Buschard, K., J. Rygaard, and E. Lund. 1976. The inability of a diabetogenic virus to induce diabetes in athymic (nude) mice. Acta Pathol. Microbiol. Scand. Sect. C 84:299-303.

7. Cohen, S. H., R. K. Naviaux, K. M. Vanderbrink, and G. W. Jordan. 1988. Comparison of the nucleotide sequences of diabetogenic and nondiabetogenic encephalomyocarditis virus. Virology 166:603-607.

8. Craighead, J. E. 1975. The role of viruses in the pathogenesis of pancreatic diseases and diabetes mellitus. Prog. Med. Virol. 19:161-214.

9. Davoren, P. R. 1962. The isolation of insulin from a single cat pancreas. Biochim. Biophys. Acta. 63:150-153.

10. Hales, C. N., and P. J. Randle. 1963. Immunoassay of insulin with insulin-antibody precipitate. J. Biochem. 88:137-146.

11. Haynes, M. K., S. A. Huber, and J. E. Craighead. 1987. Helper-inducer T-lymphocytes mediate diabetes in EMC-infected BALB/c ByJ mice. Diabetes 36:877-881.

12. Ho, M. K., and T. A. Springer. 1982. Mac-2, a novel $32,000 \mathrm{Mr}$ mouse macrophage subpopulation-specific antigen defined by monoclonal antibodies. J. Immunol. 128:1221-1228.

13. Koike, T., Y. Itoh, T. Ishii, I. Ito, K. Takabayashi, N. Maruyama, H. Tomioka, and S. Yoshida. 1987. Preventive effect of monoclonal anti- $\mathrm{L}_{3} \mathrm{~T}_{4}$ antibody on development of diabetes in NOD mice. Diabetes 36:539-541.

14. Lee, K. U., K. Amano, and J. W. Yoon. 1988. Evidence for initial involvement of macrophages in development of insulitis in NOD mice. Diabetes 37:989-991.

15. Like, A. A., C. A. Biron, E. J. Weringer, K. Byman, E. Sroczynski, and D. L. Gluberski. 1986. Prevention of diabetes in BioBreeding/Worcester rats with monoclonal antibodies that recognize $\mathrm{T}$ lymphocytes or natural killer cells. J. Exp. Med. 164:1145-1159.

16. Like, A. A., A. A. Rossini, M. C. Appel, D. L. Gluberski, and R. M. Williams. 1979. Spontaneous diabetes mellitus: reversal and prevention in the $\mathrm{BB} / \mathrm{W}$ rat with antiserum to rat lymphocytes. Science 206:1421-1423.

17. Notkins, A. L., J. W. Yoon, T. Onodera, and A. B. Jenson. 1981. Virus-induced diabetes. Perspect. Virol. XI:141-162.

18. Onodera, T., J. W. Yoon, K. Brown, and A. L. Notkins. 1978. Virus-induced diabetes mellitus: evidence for control by a single locus. Nature (London) 274:693-696.

19. Oschilewski, U., U. Kiesel, and H. Kolb. 1985. Administration of silica prevents diabetes in BB-rats. Diabetes 34:197-199.

20. Pukel, C., H. Baquerizo, and A. Rabinovitch. 1988. Destruction of rat islet cell monolayers by cytokines. Synergistic interactions of interferon- $\gamma$, tumor necrosis factor, lymphotoxin, and interleukin-1. Diabetes 37:133-136.

21. Ross, M. E., T. Onodera, K. S. Brown, and A. L. Notkins. 1976. Virus-induced diabetes mellitus. IV. Genetic and environmental factors influencing the development of diabetes after infection with the $M$ variant of encephalomyocarditis virus. Diabetes 25:190-197.

22. Sokal, R. R., and F. J. Rohlf. 1969. Biometry: the principles and practice of statistics in biological research. W. H. Freeman \& Co., San Francisco.

23. Vialettes, B., D. Baume, C. Charpin, J. De Maeyer-Guignard, and P. Vague. 1983. Assessment of viral and immune factors in EMC virus-induced diabetes: effects of cyclosporin $A$ and interferon. J. Clin. Lab. Immunol. 10:35-40.

24. Yoon, J. W. 1988. Pathogenic mechanism of virus-induced type 1 diabetes. Microb. Pathog. 5:77-86. 
25. Yoon, J. W., M. Austin, T. Onodera, and A. L. Notkins. 1979. Virus-induced diabetes mellitus. Isolation of a virus from the pancreas of a child with diabetic ketoacidosis. N. Engl. J. Med. 300:1173-1179.

26. Yoon, J. W., M. A. Lesniak, R. Fussganger, and A. L. Notkins. 1976. Genetic differences in susceptibility of pancreatic $\beta$-cells to virus-induced diabetes mellitus. Nature (London) 264:178 180.

27. Yoon, J. W., P. R. McClintock, C. J. Bachurski, J. D. Longstreth, and A. L. Notkins. 1985 . Virus-induced diabetes mellitus. No evidence for immune mechanisms in the destruction of $\beta$-cells by the $D$-variant of encephalomyocarditis virus. Diabetes 34:922-925.

28. Yoon, J. W., P. R. McClintock, T. Onodera, and A. L. Notkins. 1980. Virus-induced diabetes mellitus. XVIII. Inhibition by a non-diabetogenic variant of encephalomyocarditis virus. J. Exp. Med. 152:878-892.

29. Yoon, J. W., and A. L. Notkins. 1976. Virus-induced diabetes mellitus. VI. Genetically determined host differences in the replication of encephalomyocarditis virus in pancreatic $\beta$-cells. J. Exp. Med. 143:1170-1179.

30. Yoon, J. W., T. Onodera, and A. L. Notkins. 1977. Virus induced diabetes mellitus. VIII. Passage of encephalomyocarditis virus and severity of diabetes in susceptible and resistant strains of mice. J. Gen. Virol. 37:225-232.

31. Yoon, J. W., A. K. C. Wong, Y. S. Bae, and H. M. Eun. 1988. An apparent deletion of an oligonucleotide detected by RNA fingerprint in the nondiabetogenic B variant of encephalomyocarditis virus is due to a point mutation. J. Virol. 62:637-640. 